\title{
Digestion and absorption of refractory carbon from the plant Spartina alterniflora by the oyster Crassostrea virginica
}

\author{
Roger I. E. Newell ${ }^{1} \&$ Christopher J. Langdon ${ }^{2}$ \\ ${ }^{1}$ Center for Environmental and Estuarine Studies, Horn Point Laboratories, University of Maryland, PO Box 775, Cambridge, \\ Maryland 21613, USA \\ ${ }^{2}$ Hatfield Marine Science Center, Oregon State University, Newport, Oregon 97365, USA
}

\begin{abstract}
The vascular plant Spartina alterniflora Loisel., grown in an atmosphere containing ${ }^{14} \mathrm{CO}_{2}$, was chemically treated to produce a lignocellulosic, crude fiber material containing $0.1 \%$ lipid, no measurable protein, $4.4 \%$ starch, $85.4 \%$ cellulose and $7.7 \%$ lignin. This material was introduced, via syringe through the mouth, into the stomachs of oysters Crassostrea virginica; these were then held for $24 \mathrm{~h}$ in $13 \mathrm{ppt}$ filter-sterilized seawater at $25^{\circ} \mathrm{C}$. A second group of $\mathrm{C}$. virginica was treated identically, except for the addition of $5 \mathrm{mg} \mathrm{l}^{-1}$ of the antibiotics chloramphenicol and rifampicin to both food material and seawater. Direct enumeration (DAPI) of bacteria demonstrated that treatment with antibiotics eliminated bacteria from the oysters stomach fluid. The ${ }^{14} \mathrm{C}$ specific activities of cell-free hemolymph and tissue samples taken $24 \mathrm{~h}$ after feeding indicated that oysters were able to digest and absorb carbon from the $S$. alterniflora material with a mean efficiency of $1.3 \%$. There were no significant differences (ANOVA, $\mathrm{p}>0.05$ ) in the digestion and absorption of ${ }^{14} \mathrm{C}$ material between antibiotic treated and untreated oysters. Furthermore, in vitro cellulolytic activities of tissue homogenates of antibiotic treated oysters were not significantly different (ANOVA, $p>0.05$ ) from those of untreated oysters. These results indicate that oysters are able to digest only small amounts of refractory cellulosic material and that this process is not enhanced by bacteria present in the stomach. In vitro characterization of the cellulolytic enzymes of the crystalline style of $C$. virginica under aseptic conditions indicated the presence of $\beta$-1,4-glucanase ( $C x$ cellulase) activity that released oligosaccharides from the $S$. alterniflora material. Neither $C_{1}$ cellulase, capable of degrading crystalline cellulose, nor $\beta$-glucosidase activities were detected, using cotton fibre and cellobiose as substrates, respectively. These results suggest that the principal function of style cellulase activity is the partial depolymerisation of refractory amorphous cellulose, perhaps aiding the digestion of algal cells and detritus
\end{abstract}

\section{INTRODUCTION}

Spartina alterniflora Loisel., a dominant vascular plant in salt marshes of the Eastern United States (McIntire \& Dunstan 1976), is a major source of organic carbon to adjacent waters (Teal 1962). Living $S$. alterniflora is composed of ca 70 to $82 \%$ carbohydrate by dry weight (Squiers \& Good 1974, Smith et al. 1979), and $99 \%$ of this carbohydrate is cellulosic structural material (McIntire \& Dunstan 1976). The refractory cellulosic components may slowly decompose in situ after senesence of S. alterniflora (Smith et al. 1979, Mountford 1980), but some of the litter may be exported to adjacent estuaries during periods of high tides, unusual storms (Pickral \& Odum 1976) or as the result of ice rafting (Heinle \& Flemer 1976).

In order for this refractory cellulose to be directly utilized as a source of carbon by estuarine molluscs, such as the oyster Crassostrea virginica (Gmelin), they must possess a suite of 3 cellulolytic enzymes: (1) $C_{1}$ cellulase which acts only on crystalline, native cellulose; (2) Cx or $\beta$-1,4-glucanases which act on amorphous cellulose and soluble cellulose derivatives; (3) $\beta$ glucosidases (cellobiase) acting on cellobioses and, to a lesser extent, on other $\beta$-oligosaccharides (Mandels et al. 1976).

It is often technically difficult to determine if the complete complement of cellulases is present in living 
organisms. $\mathrm{C}_{1}$ cellulase activity has rarely been clearly demonstrated in a bivalve mollusc because researchers have not used truly crystalline cellulose substrates to test digestive enzymes. Many investigators (e.g. Payne et al. 1972) have used cellulose filter paper as a substrate for $C_{1}$ cellulase, but have not allowed for the fact that filter paper, like many other insoluble celluloses, is a complex substrate of both amorphous and crystalline cellulose (Mandels et al. 1976). Halliwell (1966) suggested the use of cotton as a crystalline cellulose substrate for determining the activity of $C_{1}$ cellulase. Koopmans (1970) found that style extracts from the bivalve Cardium edule only weakly converted cotton to reducing sugars, compared with breakdown of reprecipitated cellulose or carboxymethyl cellulose. The presence of $\beta$ - 1,4 -glucanase and $\beta$-glucosidase activities has been demonstrated in many bivalve species (Kristensen 1972, Wojtowicz 1972, Mathers 1973, Morton 1983, Lucas \& Newell 1984, Mayasich \& Smucker 1986).

Cellulolytic enzymes present in shipworms (Teredinidae) are exogenously derived from bacteria associated with the gland of Deshayes (Crosby \& Reid 1971, Waterbury et al. 1983), and gut bacteria have also been implicated in cellulose digestion by the sea urchin Strongylocentrotus droebachiensis (Fong \& Mann 1980). Conversely, Payne et al. (1972) found cellulolytic activity in the bivalve Scrobicularia plana but no evidence of cellulolytic bacteria in the clam's gut. Crosby \& Reid (1971) used histological techniques to demonstrate the presence of cellulases in the tubules of the diverticula of several bivalve species and asserted that this cellulolytic activity was partly endogenous in origin and not dependent on the presence of gut bacteria.

In this study we have examined the digestion and utilization of a refractory cellulosic material, derived by chemical extraction from Spartina alterniflora, by the American oyster Crassostrea virginica, a bivalve mollusc commonly found in estuaries draining salt marshes. The role of the crystalline style in extracellular cellulose digestion has been characterized in vitro using a range of cellulose substrates. The overall digestion of cellulose and absorption of carbon into the oyster's hemolymph have been measured in vivo using ${ }^{14} \mathrm{C}$ tracer techniques and compared in antibiotic treated and untreated oysters so as to determine the importance of enteric bacteria in cellulose digestion.

\section{METHODS}

Preparation and characterization of ${ }^{14} \mathrm{C}$-cellulose from Spartina alterniflora. Young Spartina alterniflora plants (short form) with associated soil were collected from the Canary Creek marsh, Lewes, Delaware in late May 1985 and transplanted to 41 plastic pots. Leaves and stems were trimmed to soil level and re-growth allowed to take place over a period of $2 \mathrm{wk}$. Four pots of plants were transferred to an air-tight 'Plexiglas' chamber of the type designed by Ferguson \& Williams (1974) for labelling $S$. alterniflora with ${ }^{14} \mathrm{CO}_{2}$. This method has been shown to produce $S$. alterniflora with a proximate composition very similar to that of marshgrown plants (Coston-Clements \& Ferguson 1985).

The plants were labelled with ${ }^{14} \mathrm{C}$ by growing them in an atmosphere of $0.03 \% \mathrm{v} / \mathrm{v} \mathrm{CO}_{2}$ which was partly made up with ${ }^{14} \mathrm{CO}_{2}$. Preliminary experiments indicated that the plants completely removed $0.03 \% \mathrm{v} / \mathrm{v}$ $\mathrm{CO}_{2}$ from the chamber's atmosphere over a period of $14 \mathrm{~h}$ illumination and $10 \mathrm{~h}$ darkness. Caseous ${ }^{14} \mathrm{CO}_{2}$ was produced by adding a solution of $\mathrm{NaH}^{14} \mathrm{CO}_{3}$ to $250 \mathrm{ml}$ of $1 \mathrm{M}$ citric acid solution contained in a stirred flask in the chamber. Five $\mathrm{mCi}$ of $\mathrm{NaH}^{14} \mathrm{CO}_{3}$ (specific activity $30 \mu \mathrm{Ci} \mathrm{mmol}{ }^{-1}$ ) were added to the chamber over a $5 \mathrm{~d}$ period, followed by a further $5 \mathrm{~d}$ period in which the plants were grown in a ${ }^{14} \mathrm{CO}_{2}$-free atmosphere of $0.03 \% \mathrm{CO}_{2}$. The plants were then removed from the chamber and the aerial parts harvested and dried at $60^{\circ} \mathrm{C}$ for $24 \mathrm{~h}$.

Crude fiber was prepared from dry Spartina alterni-

(1) Grind $20 \mathrm{~g}$ dry plant material in a ball-mill (Crescent 'Wig-L-Bug')

(2) Extract lipid with $150 \mathrm{ml}$ of a solution of 1 vol. chloroform and 2 vol. methanol while mixing thoroughly. (Repeat $\times 5$ )

(3) Extract protein with $100 \mathrm{ml}$ of a solution containing $25 \mathrm{ml} 10 \% \mathrm{Na}_{2} \mathrm{CO}_{3}, 25 \mathrm{ml} 0.8 \mathrm{~N} \mathrm{NaOH}, 25 \mathrm{ml}$ water and $25 \mathrm{ml} 10 \%$ lauryl sulphate. $(\times 4)$

(4) Extract with $100 \mathrm{ml}$ of $0.9 \% \mathrm{H}_{2} \mathrm{SO}_{4}$ at $95^{\circ} \mathrm{C}$ for 30 min. Wash material with $100 \mathrm{ml}$ distilled $\mathrm{H}_{2} \mathrm{O} .(\times 1)$

(5) Extract with $100 \mathrm{ml}$ of $12.5 \%(\mathrm{w} / \mathrm{v}) \mathrm{NaOH}$ at $95^{\circ} \mathrm{C}$ for $30 \mathrm{~min}$. Wash material with $100 \mathrm{ml}$ distilled $\mathrm{H}_{2} \mathrm{O}$. $(\times 1)$

(6) Dry material at $60^{\circ} \mathrm{C}$

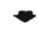

(7) Regrind material in a ball-mill. Resuspend in $1 \mathrm{M}$ $\mathrm{NaCl}_{\text {; }}$ sieve with a $20 \mu \mathrm{m}$ 'Nitex' screen and collect material $<20 \mu \mathrm{m}$. Re-dry, grind and sieve material $>20 \mu \mathrm{m}$

(8) Wash sieved material with $100 \mathrm{ml}$ sterile seawater; then wash with $100 \mathrm{ml}$ distilled $\mathrm{H}_{2} \mathrm{O} .(\times 2)$

(9) Freeze dry material and store at $-25^{\circ} \mathrm{C}$

Fig. 1. Preparation of cellulosic material from ${ }^{14} \mathrm{C}$-labelled Spartina alterniflora 
flora by acid/alkali extraction (Fig. 1), based on the method of Strickland \& Parsons (1972). The method was more extreme than commonly used for the preparation of cellulose (e.g. Whistler 1963) in order to minimize contamination by protein, lipid, starch and hemicelluloses, ${ }^{14} \mathrm{C}$ specific activity of the extracted material was $0.24 \mu \mathrm{Ci} \mathrm{mg}^{-1} \mathrm{dry}$ weight, as determined by complete oxidation and measurement of ${ }^{14} \mathrm{CO}_{2}$ trapped in a liquid scintillation medium (Benner et al. 1984). Composition and distribution of ${ }^{14} \mathrm{C}$ in the extracted material was determined using a combination of chemical and enzymatic assays:

(a) A modified Klason hydrolysis (Benner et al. 1984) was used to determine the distribution of ${ }^{14} \mathrm{C}$ between the lignin and polysaccharide fractions. This involved hydrolyzing $20 \mathrm{mg}$ samples of the Spartina alterniflora material in $0.5 \mathrm{ml}$ of $72 \%$ sulphuric acid at $30^{\circ} \mathrm{C}$ for $1 \mathrm{~h}$ with continuous shaking. The resulting suspension was then diluted with $14 \mathrm{ml}$ distilled water and autoclaved at 15 psi and $121^{\circ} \mathrm{C}$ for $1 \mathrm{~h}$. This procedure hydrolyses polysaccharides, whereas lignin condenses and remains insoluble (Benner et al. 1984). The tubes were centrifuged at $1200 \mathrm{~g}$ for $10 \mathrm{~min}$ and the supernatant filtered through a $0.2 \mu \mathrm{m}$ Nuclepore filter. The pellet was resuspended in $10 \mathrm{ml}$ distilled water at $80^{\circ} \mathrm{C}$ and the suspension refiltered with a $0.2 \mu \mathrm{m}$ Nuclepore filter. The filter was washed with a further $5 \mathrm{ml}$ of distilled water. ${ }^{14} \mathrm{C}$ activity in the hydrolysate was expressed as a percentage of the combined radioactivities of the pellet and filtrates.

(b) The percentage of ${ }^{14} \mathrm{C}$ in the cellulose fraction from $10 \mathrm{mg}$ of Spartina alterniflora material was estimated by enzyme digestion with a mixture of cellulases from Trichoderma viride (Sigma type V) and Aspergillus niger (Sigma type II) made up in $0.1 \mathrm{M}$ acetate buffer ( $\mathrm{pH}$ 5.0) containing 20 ppm Thimerosal. The cellulase activity of this mixture was composed of equal activities of $T$. viride and $A$. niger cellulases and was sufficient to break down completely $10 \mathrm{mg}$ of pure cellulose to glucose in $2 \mathrm{~h}$ at $37^{\circ} \mathrm{C}$. Assay tubes were incubated by shaking for $24 \mathrm{~h}$ at $25^{\circ} \mathrm{C}$. Control tubes containing only acetate buffer and cellulosic material were used to estimate leaching rates. The amount of ${ }^{14} \mathrm{C}$ label solubilized by the cellulases, minus that released by leaching, was expressed as a percentage of the combined radioactivities of the pellet and filtrates.

(c) The proportion of ${ }^{14} \mathrm{C}$ in the form of starch was estimated by incubating $20 \mathrm{mg}$ of the ${ }^{14} \mathrm{C}$ cellulosic material with $\alpha$-amylase (Bacillus sp., Sigma type II-A) and determining the release of soluble ${ }^{14} \mathrm{C}$. The $\alpha$ amylase preparation was found to have detectable cellulolytic activity when incubated with highly purified cellulose (Sigmacell, Sigma). Potential liberation of ${ }^{14} \mathrm{C}$ from the cellulose component of the Spartina alterniflora material by this enzyme preparation was minimized by the addition of excess non-radioactive cellulose to the assays $(40: 1 \mathrm{~W} / \mathrm{W}$, Sigmacell: ${ }^{14} \mathrm{C}$ S. alterniflora material) to saturate the contaminating cellulase activity. Addition of this quantity of cellulose had no effect on $\alpha$-amylase activity.

The $\alpha$-amylase was made up in $0.22 \mu$ m filtered, autoclaved seawater (sterile seawater) at salinity 13 to 14 ppt, pH 6.9 and containing 20 ppt of the antibiotic Thimerosal. The amount of enzyme used in the assay was sufficient to convert completely $20 \mathrm{mg}$ of starch to maltose in $1 \mathrm{~min}$ at $37^{\circ} \mathrm{C}$ and $\mathrm{pH} 6.9$.

After digestion of the Spartina alterniflora material for $24 \mathrm{~h}$ at $25^{\circ} \mathrm{C}$ (with continous shaking), the suspension was centrifuged at $1200 \mathrm{~g}$ for $10 \mathrm{~min}$ and the supernatant filtered through a $0.2 \mu \mathrm{m}$ Nuclepore filter. $S$. alterniflora material suspended in sterile seawater was used as a control for leaching. The percentage ${ }^{14} \mathrm{C}$ solubilized by $\beta$-amylase was expressed as in (b).

(d) Lipids were extracted with chloroform/methanol (Holland \& Gabbott 1971). The specific activity of the lipid extract was expressed as a percentage of the specific activities of the extract and pellet combined.

(e) Protein was extracted by boiling in $0.5 \mathrm{M} \mathrm{NaOH}$ for $10 \mathrm{~min}$. After centrifugation $(1000 \mathrm{~g})$ for $10 \mathrm{~min}$, the protein content of the supernatant was determined using the method of Lowry et al. (1951) as modified by Rice (1982) to correct for interference by phenolic compounds from associated lignin. Bovine serum albumen was used as a standard.

In vitro estimates of oyster cellulase activity. Preparation of style and digestive gland extracts. Crassostrea virginica (shell height 10 to $12 \mathrm{~cm}$; mean [士 SE] dry tissue weight $=1.35 \pm 0.031 \mathrm{~g}$ ) were collected in October from the Choptank River, Maryland and held in the laboratory for 10 to $20 \mathrm{~d}$ in a constant flow of unfiltered seawater pumped from the Choptank River estuary (ambient temperature 16 to $17^{\circ} \mathrm{C}$, salinity 13 to $14 \mathrm{ppt}$ ). Styles were removed from oysters and immediately added to chilled sterile seawater, containing $20 \mathrm{ppt}$ Thimerosal, resulting in a concentration of 0.65 styles $\mathrm{ml}^{-1}$. Styles were homogenized in a glass Potter Elvehjem homogeniser to aid dissolution after which the preparation was centrifuged at $1000 \mathrm{~g}$ for $10 \mathrm{~min}$ to remove insoluble particulate matter. The $\mathrm{pH}$ of sterile seawater was adjusted to 6.9 with dilute $\mathrm{HCl}$ in order to approximate the $\mathrm{pH}$ of the oyster stomach and style sac (Morton 1983).

The digestive glands of 21 oysters were removed and gently homogenized in $100 \mathrm{ml}$ of sterile seawater (pH6.9). The homogenate was vacuum filtered at $<5 \mathrm{~mm} \mathrm{Hg}$ through a $30 \mu \mathrm{m}$ Nitex screen. Both digestive gland and style homogenates were stored at $4{ }^{\circ} \mathrm{C}$ for no more than $2 \mathrm{~h}$ before use. The protein contents of both homogenates were determined using the method of Lowry et al. (1951). 
Assay of style cellulase activity. Four cellulose substrates were used to test style cellulase activity: (1) pharmaceutical grade cotton balls, pre-washed in hexane to remove any wax or oil coating; (2) non $-{ }^{14} \mathrm{C}$ labelled Spartina alterniflora, prepared as detailed in Fig. 1 ; (3) cellulose azure (Sigma Type I) which releases a dye (absorbance $595 \mathrm{~nm}$ ) as a result of breakdown by cellulases; (4) cellobiose (Sigma) to test for the presence of $\beta$-glucosidase. All substrates were added at a concentration of $0.5 \% \mathrm{~W} / \mathrm{V}$ to the enzyme preparations together with an antibiotic mix of $20 \mathrm{ppm}$ Thimerosal and $2 \% \mathrm{~V} / \mathrm{V}$ toluene to inhibit bacterial activity. The tubes were incubated on a shaker table at $25^{\circ} \mathrm{C}$ for $24 \mathrm{~h}$, a period that ensured measurable levels of enzyme product. Each assay was performed in triplicate.

Assays were terminated by immersing them in a boiling water bath to denature the enzymes. Each tube was centrifuged at $1400 \mathrm{~g}$ for $10 \mathrm{~min}$ and the supernatant filtered through a $0.2 \mu \mathrm{m}$ Nuclepore filter. Glucose concentration was determined using a hexokinase enzymatic test kit (Sigma $16 \mathrm{UV}$ ), standardized with $\alpha$ $\mathrm{D}(+)$ glucose. Total carbohydrate concentration was determined using the phenol-sulphuric acid method of Dubois et al. (1956), also standardized with glucose. The relation between cellulose azure dye release and total carbohydrate release was determined and described by the following regression equation:

$$
A=(0.000462 \times C)+0.00728(n=17 ; r=0.943)
$$

where $\mathrm{A}=$ absorbance at $595 \mathrm{~nm} ; \mathrm{C}=$ concentration of $\alpha-\mathrm{D}(+)$ glucose in $\mu \mathrm{g} \mathrm{ml} \mathrm{m}^{-1}$.

Initial glucose, total carbohydrate and azure concentrations were determined in control tubes boiled immediately upon addition of the enzyme to the substrate. Additional control tubes, containing only enzyme or substrate in sterile water, were boiled at time zero and after the $24 \mathrm{~h}$ incubation to determine the rate of release of product from sources other than cellulase acting on the cellulose substrate.

Assay of digestive gland cellulase activity. Substantial release of glucose and soluble carbohydrate from digestive gland autolysis masked the in vitro release of these end-products by cellulase activity. Therefore, cellulose azure was used as a substrate to avoid this difficulty. The experimental protocol was identical to that described above for the style, except that the incubation period was increased to $168 \mathrm{~h}$ to ensure a measurable concentration of released azure. Digestive gland samples turned cloudy upon boiling and so could not be used as controls. Instead, assay tubes containing only digestive gland or cellulose azure in sterile water with $2 \% \mathrm{~V} / \mathrm{V}$ toluene and $20 \mathrm{ppm}$ Thimerosal were used as controls. At the end of the incubation period, samples were centrifuged at $1400 \mathrm{~g}$ for $10 \mathrm{~min}$, the supernatant filtered (Whatman $\mathrm{GF} / \mathrm{C}$ ), and the amount of azure released determined.

In Vivo ${ }^{14} \mathrm{C}$ absorption experiment. Oyster feeding. Thirty-six Crassostrea virginica (shell height 10 to $12 \mathrm{~cm}$ ) collected and held as above were scrubbed clean of epibionts. Shell-boring polychaetes were removed by 2 consecutive, $5 \mathrm{~min}$ immersions in $0.1 \%$ $\mathrm{V} / \mathrm{V}$ domestic hypochlorite solution ('Chlorox'). Ventral margins of both left and right valves of the oysters were partially removed using a high-speed diamond saw to expose gills and labial palps. The hood formed by anterior fusion of the 2 mantle folds (Galtsoff 1964) was cut to expose the mouth. Fluid from oesophagus and stomach was collected using a Pasteur pipette inserted through the mouth and stored at $5^{\circ} \mathrm{C}$ with $1 \%$ W/V (final concentration) formalin added, for estimation of bacteria concentrations (see below). The described manipulation of the oysters did not cause fatal injury because oysters survived and after several weeks showed signs of shell repair.

One hundred $\mu \mathrm{l}$ of a suspension of $38.1 \mathrm{mg} \mathrm{ml}^{-1}{ }^{14} \mathrm{C}$ labelled Spartina alterniflora material $\left(9.14 \mu \mathrm{Ci} \mathrm{m}{ }^{-1}\right)$ made up in sterile seawater were introduced by syringe through the mouth and into the stomach of each of 12 oysters. A second group of 12 oysters was similarly fed the same amount of material made up in sterile seawater containing $5 \mathrm{mg} \mathrm{l}^{-1}$ each of the antibiotics chloramphenicol and rifampicin. Langdon \& Bolton (1984) found that this antibiotic mixture added to seawater had no adverse effects on either the filtration rate or growth of Crassostrea virginica. Control groups of 4 oysters had either $100 \mu l$ of sterile seawater or $100 \mu \mathrm{l}$ of sterile water containing both antibiotics introduced into their stomachs.

Antibiotic or non-antibiotic treated oysters were placed in separate $0.22 \mu \mathrm{m}$ filtered, $20 \mathrm{l}$ volumes of seawater $\left(13 \mathrm{ppt}, 25^{\circ} \mathrm{C}\right)$. Five $\mathrm{mg} \mathrm{l^{-1 }}$ of each of the antibiotics chloramphenicol and rifampicin were added to the seawater in which antibiotic-treated oysters were held. Seawater in both aquaria was replaced after $15 \mathrm{~h}$ of incubation with fresh, $0.22 \mu \mathrm{m}$ filtered seawater.

Hemolymph collection and analysis. In order to estimate the rate and time course of ${ }^{14} \mathrm{C}$ absorption into the circulatory system of Crassostrea virginica, $500 \mu \mathrm{l}$ samples of hemolymph were periodically withdrawn by syringe from the sinus of the adductor muscle. Hemolymph samples were taken from oysters at the start of the experiment to estimate background radioactivity. Six fed oysters from each of the antibiotic and non-antibiotic treatments were sampled at 5 and $24 \mathrm{~h}$ after the beginning of the experiment and 6 were sampled after 15 and $24 \mathrm{~h}$. Unfed oysters were sampled at $15 \mathrm{~h}$ and $24 \mathrm{~h}$.

Hemolymph was drawn into $500 \mu l$ of artificial sea- 
water (salinity $12 \mathrm{ppt}_{\text {; }}$ free of $\mathrm{Ca}^{++}$and $\mathrm{Mg}^{++}$) containing $2 \mathrm{~W} / \mathrm{V}$ sodium ethylenediaminetetracetate (Fisher \& Newell 1986). The hemolymph sample was centrifuged at $1000 \mathrm{~g}$ for $10 \mathrm{~min}$ and the supernatant removed. The pellet was washed twice with $1.0 \mathrm{ml}$ of sterile seawater and resuspended in $0.5 \mathrm{ml}$ of sterile seawater. The ${ }^{14} \mathrm{C}$ specific activities of the pellet and supernatant were determined.

Digestion and incorporation of ${ }^{14} \mathrm{C} S$. alterniflora material. Digestion and incorporation of ${ }^{14} \mathrm{C}$ into oyster tissue was determined by homogenizing individual body tissues in $10 \mathrm{ml}$ of sterile seawater, extracting $1 \mathrm{ml}$ of the homogenate with acid and alkali, followed by centrifugation (Fig. 2). The ${ }^{14} \mathrm{C}$ specific activity of $1.0 \mathrm{ml}$ of the supernatant solutions and all pellets were determined. The supernatant radioactivity came from ${ }^{14} \mathrm{C}$ incorporated in oyster tissues, as well as ${ }^{14} \mathrm{C}$ that had been digested but not absorbed at the time the experiment was terminated. In addition, the acid/ alkali extraction solubilised $35.1 \%$ of the ${ }^{14} \mathrm{C}$ from the undigested cellulosic food material present in the oyster's digestive system (Table 1 ). The pellet contained $64.9 \%$ of the remaining ${ }^{14} \mathrm{C}$ undigested food material. The specific activities of oyster tissue extracts were therefore corrected for this solublization by acid/alkali treatment of food remaining in the gut. Specific activities were corrected for quenching and expressed on a per oyster basis.

Cellulose breakdown by bacteria present in tissue homogenates from individual oysters that were either treated or not treated with antibiotics was assessed using cellulose azure as a substrate. The protocol was the same as that described above for digestive gland

(1) Homogenize oyster tissue in $10 \mathrm{ml}$ of sterile distilled water

\section{$-$}

(2) Heat $1 \mathrm{ml}$ of homogenate $+10 \mathrm{ml} 0.9 \%(\mathrm{v} / \mathrm{v})$ $\mathrm{H}_{2} \mathrm{SO}_{4}$ at $95^{\circ} \mathrm{C}$ for $30 \mathrm{~min}$

$-$

(3) Centrifuge at $1400 \mathrm{~g}$ for $10 \mathrm{~min}$. Remove $1 \mathrm{ml}$ of supernatant for ${ }^{14} \mathrm{C}$ determination. Aspirate and discard remaining supernatant

$-$

(4) Pellet $+10 \mathrm{ml}$ distilled water, vortex and centrifuge at $1400 \mathrm{~g}$ for $10 \mathrm{~min}$

$$
-
$$

(5) Heat resuspended pellet $+10 \mathrm{ml}$ of $12.5 \%(\mathrm{w} / \mathrm{v})$ $\mathrm{NaOH}$ at $95^{\circ} \mathrm{C}$ for $30 \mathrm{~min}$

(6) Centrifuge at $1400 \mathrm{~g}$ for $10 \mathrm{~min}$. Remove $1 \mathrm{ml}$ of supernatant for ${ }^{14} \mathrm{C}$ determination. Aspirate and discard remaining supernatant

(7) Wash pellet as in (4). Transfer pellet to Aquasol for ${ }^{14} \mathrm{C}$ determination. Add sufficient $\mathrm{H}_{2} \mathrm{O}$ to form gel

Fig. 2. Determination of ${ }^{14} \mathrm{C}$ in oyster tissues

assays, except that styles were not removed prior to homogenization.

Bacteria concentrations. In the feeding experiment bacteria concentrations were estimated by staining the bacteria with 4,6-diamidino-2-phenylindole (DAPI; Sigma) and directly counting the bacterial cells under UV illumination (Porter \& Feig 1980). Concentrations of bacteria were determined in samples of stomach fluids from both antibiotic and non-antibiotic treated oysters at the beginning and end of the feeding experiment. Concentrations of bacteria present in seawater samples from the $20 \mathrm{l}$ aquaria were also determined just prior to the water being changed at 15 and $24 \mathrm{~h}$.

Statistical analyses. The General Linear Models procedure (Statistical Analysis System Institute, Inc.) for an unbalanced ANOVA was used to analyze these data.

\section{RESULTS}

\section{Distribution of ${ }^{14} \mathrm{C}$ in extracted Spartina alterniflora}

Enzymatic digestion indicated that $85.4 \%$ of the ${ }^{14} \mathrm{C}$ was present in material susceptible to cellulolytic breakdown (Table 1). Klason hydrolysis indicated that $92.3 \%$ of ${ }^{14} \mathrm{C}$ was present in the polysaccharide fraction and $7: 7 \%$ in the lignin fraction. Protein and lipid contamination of the extracted material was negligible and $4.4 \%$ of the ${ }^{14} \mathrm{C}$ present was available as a substrate for $\alpha$-amylase.

\section{In vitro determination of cellulase activity}

Style and digestive gland cellulases liberated oligosaccharides from the extracted Spartina alterniflora material and from cellulose azure, indicating the

Table 1. Spartina alterniflora. Characterization of acid/alkali extracted, ${ }^{14} \mathrm{C}$-labelled plants. All values are means $\pm \mathrm{SE}$.

Number of replicates was 3 , except where indicated

Particle diameter

Percent ${ }^{14} \mathrm{C}$ solubilised by

(a) 24 h incubation in sterile seawater

(b) second acid/alkali extraction (see Fig. 1)

Percent distribution of ${ }^{14} \mathrm{C}$

Lignin (Klason hydrolysis)

Polysaccahride (Klason hydrolysis)

Cellulose (cellulase digestion)

Starch ( $\alpha$-amylase digestion)

Lipid (methanol/chloroform extraction)

Protein

- $\mathrm{nd}=$ not detectable

$$
<20 \mu \mathrm{m}
$$

$1.6 \pm 0.28$

$35.1 \pm 1.34$

$(\mathrm{n}=5)$

$7.7 \pm 0.31$

$92.3 \pm 0.31$

$85.4 \pm 0.40$

$4.4 \pm 0.15$

$0.1 \pm 0.001$

nd ${ }^{*}$ 
Table 2. Crassostrea virginica. Mean ( $\pm \mathrm{SE}) \mu \mathrm{g}$ glucose and $\mu \mathrm{g}$ total carbohydrate (glucose equivalents) released per mg protein in $24 \mathrm{~h}$ by style and digestive gland preparations. All assays were performed with $20 \mathrm{mg} \mathrm{l}^{-1}$ Thimerosal and $2 \%$ toluene added Concentration of all substrates was $0.5 \%$ W/V. Number of replicates was 4 , except where otherwise indicated

\begin{tabular}{|lcr|}
\hline Substrate & $\begin{array}{c}\mu \text { g glucose released } \\
\mathrm{mg}^{-1} \text { protein } 24 \mathrm{~h}^{-1}\end{array}$ & $\begin{array}{c}\mu g \text { carbohydrate released } \\
\mathrm{mg}^{-1}{\text { protein } 24 \mathrm{~h}^{-1}}\end{array}$ \\
\hline Style & & $88.3 \pm 11.43$ \\
Spartina alterniflora & $1.64 \pm 0.48$ & $517.3 \pm$ \\
Cellulose azure & $2.67 \pm 0.38$ & 0 \\
Cotton & 0 & 0.37 \\
Cellobiose & 0 & $0.16 \pm 0.004$ \\
Digestive gland & & $(\mathrm{n}=6)$ \\
Cellulose azure & &
\end{tabular}

presence of $\beta$-1,4-glucanases (Table 2). $\beta$-1,4-glucanase activity was also present in diverticula preparations as demonstrated by the breakdown of cellulose azure. In contrast, rates of glucose liberation from all substrates by style $\beta$-1,4-glucanases were negligible. No glucose was liberated from cellobiose by the style indicating an absence of $\beta$-glucosidase activity. Furthermore, the style preparation was not capable of breaking down cotton fibers under the conditions of the assay, suggesting an absence of $C_{1}$ cellulase.

\section{In vivo digestion and absorption of ${ }^{14} \mathrm{C}$}

Five $h$ after being fed ${ }^{14} \mathrm{C}$ labelled cellulosic material, oysters had ${ }^{14} \mathrm{C}$ specific activities significantly greater than background in both hemolymph plasma (ANOVA, $\mathrm{p}<0.002$ ) and pellet fractions (ANOVA, $\mathrm{p}<0.01$ ). The plasma ${ }^{14} \mathrm{C}$ activities (Table 3 ) did not significantly change between 5 and $24 \mathrm{~h}$ after feeding (ANOVA, $\mathrm{p}>0.05$ ). However, hemolymph pellet ${ }^{14} \mathrm{C}$ activities did significantly differ (ANOVA, $\mathrm{p}=0.018$ ) between the 3 sampling times (Table 3 ), with significantly higher activity at $5 \mathrm{~h}$ compared to 15 and $24 \mathrm{~h}$ (t-test; $\mathrm{p}<0.05$ ). Unfed control oysters held in the same 20 I volume of seawater as fed oysters had hemolymph plasma and pellet ${ }^{14} \mathrm{C}$ specific activities slightly above background. This accumulation of ${ }^{14} \mathrm{C}$ by unfed oysters may have been due to uptake of dissolved organic material ( $\mathrm{DO}^{14} \mathrm{C}$ ) leaching into the seawater (Table 1) from particulate ${ }^{14} \mathrm{C}$ cellulosic material fed to the other oysters. Specific activities of $\mathrm{DO}^{14} \mathrm{C}$ in $0.22 \mu \mathrm{m}$ filtered seawater samples taken from both aquaria at $15 \mathrm{~h}$ and at the end of the $24 \mathrm{~h}$ incubation period (Table 4) were not significantly different (ANOVA, $p>0.05$ ). Overall, the ${ }^{14} \mathrm{C}$ activities in plasma and pellet hemolymph fractions of ${ }^{14} \mathrm{C}$ fed oysters were significantly greater (ANOVA, $p=0.002$ [plasma]; $\mathrm{p}=0.017$ [pellet]) than those of unfed oysters (Table 3).
The ${ }^{14} \mathrm{C}$ specific activities of tissue extracts of fed oysters was significantly greater (ANOVA, $\mathrm{p}<0.0001$ ) than those of unfed controls (Table 5). The ${ }^{14} \mathrm{C}$ specific activities of tissue extracts from unfed controls held in the same seawater as fed oysters were above background at the end of the $24 \mathrm{~h}$ incubation (Table 5), again indicating slight uptake of $\mathrm{DO}^{14} \mathrm{C}$.

${ }^{14} \mathrm{C}$ specific activities of hemolymph or tissue samples from oysters treated or untreated with antibiotics were not significantly different at the end of the feeding experiment (Tables $3 \& 5$ ). Antibiotics were effective in maintaining low concentrations of bacteria in the $0.22 \mu \mathrm{m}$ filtered seawater of the experimental aquarium (Table 4). Bacteria were not detected in stomach fluid samples of antibiotic treated oysters, in contrast to a concentration of $1.62 \pm 0.11(\mathrm{SE}) \times 10^{7}$ bacteria $\mathrm{ml}^{-1}$ in stomach fluid samples of non-antibiotic treated oysters at the end of the $24 \mathrm{~h}$ feeding experiment.

Treatment of live oysters with the antibiotics rifampicin and chloramphenicol had no significant effect on cellulase activity of tissue homogenates, measured using cellulose azure as the substrate (Table 6; ANOVA, $p=0.13$ ). When the antibiotics toluene and Thimerosal were included in enzyme assays, cellulolytic activity was significantly enhanced (ANOVA, $\mathrm{p}<0.0001)$

\section{DISCUSSION}

A Klason hydrolysis of the extracted ${ }^{14} \mathrm{C}$ labelled Spartina alterniflora indicated that $92.3 \%$ of the ${ }^{14} \mathrm{C}$ was present in the polysaccharide fraction and that $7.7 \%$ of the ${ }^{14} \mathrm{C}$ was incorporated in lignin (Table 1 ). Treatment with cellulase showed that $92.5 \%$ of the ${ }^{14} \mathrm{C}$ in the polysaccharide fraction (as defined by Klason hydrolysis), or $85.4 \%$ of the total particulate ${ }^{14} \mathrm{C}$, was bound in material susceptible to cellulase action. 
Table 3. Crassostrea virginica. Radioactivity (mean dpm $\pm \mathrm{SE}$ ) $\mathrm{ml}^{-1}$ hemolymph from oysters fed extracted ${ }^{14} \mathrm{C}$ labelled Spartina alterniflora or from unfed oysters. Unfed and fed oysters were kept in the same aquarium during the experiment. Five mg $\mathrm{l}^{-1}$ each of antibiotics rifampicin and chloramphenicol were added to filter-, sterilized seawater in which antibiotic treated oysters were held. Number of replicates in parenthesis. Dpm values corrected for background radioactivity

\begin{tabular}{|c|c|c|c|c|}
\hline \multirow{3}{*}{$\begin{array}{l}\text { Time }(\mathrm{h}) \text { bled } \\
\text { after feeding }\end{array}$} & \multicolumn{4}{|c|}{ Radioactivity (DPM $\pm \mathrm{SE})$} \\
\hline & \multicolumn{2}{|c|}{ Plasma of hemolymph } & \multicolumn{2}{|c|}{ Pellet of hemolymph } \\
\hline & $\begin{array}{l}\text { Antibiotic- } \\
\text { treated }\end{array}$ & $\begin{array}{c}\text { Non-antibiotic- } \\
\text { treated }\end{array}$ & $\begin{array}{l}\text { Antibiotic- } \\
\text { treated }\end{array}$ & $\begin{array}{c}\text { Non-antibiotic- } \\
\text { treated }\end{array}$ \\
\hline \multicolumn{5}{|l|}{ Fed oysters } \\
\hline 5 & $\begin{aligned} & 732.2 \\
& \pm \quad 240.1(6)\end{aligned}$ & $\begin{aligned} & 813.2 \\
&+\quad 150.1(6)\end{aligned}$ & $\begin{array}{r}34.2 \\
\pm \quad 8.1(6)\end{array}$ & $\begin{aligned} & 88.7 \\
\pm & 33.9(6)\end{aligned}$ \\
\hline 15 & $\begin{array}{r}1171.4 \\
+\quad 318.2(5)\end{array}$ & $\begin{array}{r}1247.8 \\
+\quad 735.2(5)\end{array}$ & $\begin{array}{r}20.8 \\
+\quad 5.4(5)\end{array}$ & $\begin{array}{r}18.4 \\
\pm \quad 5.8(6)\end{array}$ \\
\hline 24 & $\begin{array}{l}1076.1 \\
+\quad 418.3(11)\end{array}$ & $\begin{aligned} & 739.1 \\
& \pm \quad 141.9(11)\end{aligned}$ & $\begin{aligned} & 10.6 \\
\pm & 13.5(11)\end{aligned}$ & $\begin{aligned} & 23.9 \\
\pm & 10.6(11)\end{aligned}$ \\
\hline \multicolumn{5}{|l|}{ Unfed oysters } \\
\hline 15 & $\begin{array}{l}12.3 \\
\pm 1.8(4)\end{array}$ & $\begin{array}{l}12.5 \\
\pm 1.4(4)\end{array}$ & $\begin{aligned} & 12.8 \\
& \pm \quad 1.5(4)\end{aligned}$ & $\begin{aligned} & 14.5 \\
& \pm \quad 1.5(4)\end{aligned}$ \\
\hline 24 & $\begin{aligned} & 6.5 \\
\pm & 1.7(4)\end{aligned}$ & $\begin{aligned} & 5.4 \\
\pm & 1.5(4)\end{aligned}$ & $\begin{array}{l}-2.8 \\
\pm \quad 4.7(4)\end{array}$ & $\begin{array}{l}-1.5 \\
\pm \quad 2.2(4)\end{array}$ \\
\hline \multicolumn{5}{|c|}{ ANOVA table for hemolymph plasma and pellet data presented above: } \\
\hline Source & DF & SS & $\mathrm{F}$ & $\mathrm{p}$ \\
\hline \multicolumn{5}{|l|}{ Plasma } \\
\hline Fed/unfed & 1 & 10589780 & 15.77 & 0.0002 \\
\hline Antibiotic treatment & 1 & 51571 & 0.08 & 0.783 \\
\hline Interaction & 1 & 50278 & 0.07 & 0.785 \\
\hline Error & 57 & 38266187 & & \\
\hline \multicolumn{5}{|l|}{ Pellet } \\
\hline Fed/unfed & 1 & 9959 & 5.98 & 0.017 \\
\hline Antibiotic treatment & 1 & 1662 & 1.0 & 0.322 \\
\hline Interaction & 1 & 1067 & 0.64 & 0.427 \\
\hline Error & 57 & 109764 & & \\
\hline
\end{tabular}

Biologically degradable cellulose therefore formed a major component of the extracted $S$. alterniflora.

Our in vitro assays of style preparations indicated an absence of $C_{1}$ cellulase activity and the presence of $\beta$ 1,4-glucanase activity. The style cellulases are therefore capable of breaking down amorphous cellulose but not crystalline cellulose. Lucas \& Newell (1984) have also reported the presence of $\beta-1,4$-glucanase in style preparations of Crassostrea virginica. We found no $\beta$-glucosidase activity in the style, which is consistent with the findings of Mayasich \& Smucker (1986) for $C$. virginica, however the latter researchers found $\beta$-glucosidase activity in the digestive diverticula.

Although an enzymatic approach to the study of cellulose digestion can demonstrate the presence or absence of cellulases, it is difficult to use the results to assess the quantitative importance of cellulase activity in the supply of carbon to the living oyster. A more realistic determination of the oyster's ability to digest refractory cellulosic material and of the quantitative importance of this source of carbon to the animal's nutrition can be obtained by means of ${ }^{14} \mathrm{C}$ radiotracer studies.

The results of our ${ }^{14} \mathrm{C}$ radiotracer study demonstrate that Crassostrea virginica can digest and absorb small amounts of carbon from the cellulosic material prepared from Spartina alterniflora. ${ }^{14} \mathrm{C}$ specific activities of hemolymph and pellet samples were significantly higher (ANOVA, $p=0.0002$ and $p=0.017$, respectively) in oysters fed ${ }^{14} \mathrm{C}$ material than in unfed oysters (Table 3). These results demonstrate that the ${ }^{14} \mathrm{C}$ labelled material was digested and absorbed into the hemolymph. Specific activities of ${ }^{14} \mathrm{C}$ in tissue extracts of $C$. virginicia were also significantly higher (ANOVA, $p<0.0001$ ) in fed than in unfed oysters (Table 5).

Mean digestion efficiency of $1.3 \%$ for oysters fed on the Spartina alterniflora material was low and even 
this low level may have been due to the action of either cellulase and/or amylase enzymes (Table 1). However, our experimental oysters were pre-fed on natural ses- ton. We are currently studying the possibility that there may be enhanced cellulose digestion in oysters preconditioned by feeding them a diet rich in cellulose.

Table 4. Bacteria numbers $\mathrm{ml}^{-1}$ (mean $\pm \mathrm{SE}$ ) and radioactivity $\mathrm{ml}^{-1}$ (mean $\mathrm{dpm} \pm \mathrm{SE}$ ) in the seawater in which Crassostrea virginica fed ${ }^{14} \mathrm{C}$ Spartina alterniflora material were held. Dpm values corrected for background activity. Number of replicates in parenthesis

\begin{tabular}{|c|c|c|}
\hline \multirow[t]{2}{*}{ Time (h) after feeding oysters } & \multicolumn{2}{|c|}{ Aquarium } \\
\hline & With antibiotics & Without antibiotics \\
\hline \multicolumn{3}{|l|}{ Bacteria numbers } \\
\hline 15 & $\begin{array}{c}7.4 \pm 0.52 \times 10^{4} \\
(\mathrm{n}=16)\end{array}$ & $\begin{array}{c}5.43 \pm 0.55 \times 10^{6} \\
(\mathrm{n}=7)\end{array}$ \\
\hline 24 & $\underset{(\mathrm{n}=8)}{8.1 \pm 1.2 \times 10^{4}}$ & $\begin{array}{c}5.87 \pm 0.63 \times 10^{6} \\
(\mathrm{n}=8)\end{array}$ \\
\hline \multicolumn{3}{|l|}{ Radioactivity } \\
\hline 15 & $\begin{array}{c}13.0 \pm 2.54 \\
(\mathrm{n}=3)\end{array}$ & $\begin{array}{c}13.8 \pm 5.31 \\
(\mathrm{n}=3)\end{array}$ \\
\hline 24 & $\begin{array}{c}13.8 \pm 0.58 \\
(\mathrm{n}=3)\end{array}$ & $\begin{array}{c}11.0 \pm 0.81 \\
(n=3)\end{array}$ \\
\hline
\end{tabular}

Table 5. Crassostrea virginica. Total radioactivity of body tissue extracts of individual oysters (dpm oyster ${ }^{-1}$ ). Oysters were either fed $2016333 \mathrm{dpm}{ }^{14} \mathrm{C}$ labelled Spartina alterniflora or unfed. Unfed and fed oysters were kept in the same aquarium during the experiment. Five $\mathrm{mg} \mathrm{l}^{-1}$ each of antibiotics rifampicin and chloramphenicol were added to filter-sterilized seawater in which antibiotic-treated oysters were held. Dpm values corrected for background radioactivity

\begin{tabular}{|c|c|c|c|c|c|}
\hline \multicolumn{3}{|c|}{ Antibiotic-treated oysters } & \multicolumn{3}{|c|}{ Non-antibiotic-treated oysters } \\
\hline & ${ }_{\text {DPM }}^{\text {Antibiotic-t }}$ & Digestion efficiency & \multicolumn{2}{|c|}{ DPM } & Digestion efficiency \\
\hline \multicolumn{6}{|l|}{ Fed oysters } \\
\hline & 9330 & 0.46 & \multicolumn{2}{|c|}{12005} & 0.60 \\
\hline & 9468 & 0.47 & \multicolumn{2}{|c|}{12696} & 0.63 \\
\hline & 14553 & 0.72 & \multicolumn{2}{|c|}{14289} & 0.71 \\
\hline & 15357 & 0.76 & \multicolumn{2}{|c|}{18866} & 0.90 \\
\hline & 22468 & 1.11 & \multicolumn{2}{|c|}{22545} & 1.12 \\
\hline & 25706 & 1.27 & \multicolumn{2}{|c|}{24988} & 1.24 \\
\hline & 27156 & 1.35 & \multicolumn{2}{|c|}{25545} & 1.27 \\
\hline & 27468 & 1.36 & \multicolumn{2}{|c|}{34477} & 1.71 \\
\hline & 30786 & 1.53 & \multicolumn{2}{|c|}{35486} & 1.76 \\
\hline & 41047 & 2.04 & \multicolumn{2}{|c|}{36334} & 1.80 \\
\hline & 53025 & 2.63 & \multicolumn{2}{|c|}{50822} & 2.50 \\
\hline Mean $\pm \mathrm{SE}$ & $25124 \pm 4025$ & $1.25 \%$ & 26186 & & $1.30 \%$ \\
\hline \multicolumn{6}{|l|}{ Unfed oysters } \\
\hline & 600 & & \multicolumn{2}{|c|}{283} & \\
\hline & 128 & & \multicolumn{2}{|c|}{107} & \\
\hline & 268 & & \multicolumn{2}{|c|}{453} & \\
\hline & 372 & & 436 & & \\
\hline Mean $\pm \mathrm{SE}$ & $342 \pm 99$ & & 319 & & \\
\hline ANOVA table for & r data presented & & & & \\
\hline Source & & DF & SS & $F$ & p \\
\hline Fed/unfed & & 1 & 3762373174 & 30.18 & 0.0001 \\
\hline Antibiotic trea & atment & 1 & 1585861 & 0.01 & 0.911 \\
\hline Interaction & & 1 & 1724499 & 0.01 & 0.907 \\
\hline ErIor & & 29 & 3241517907 & & \\
\hline
\end{tabular}


Table 6. Cellulase activity measured by cellulose azure breakdown; expressed as $\mu \mathrm{g}$ carbohydrate released in $24 \mathrm{~h}$ per $100 \mathrm{mg}$ (dry wt) of homogenized tissue (including style) from Crassostrea virginica treated or not treated with 5 mg $\mathrm{l}^{-1}$ each of antibiotics rifampicin and chloramphenicol. Enzyme assays performed with or without $20 \mathrm{mg} \mathrm{l}^{-1}$ Thimerosal and $2 \% \mathrm{~V} / \mathrm{V}$ toluene added to incubation tubes. Values are means \pm SE. Number of replicates in parenthesis

\begin{tabular}{|c|c|c|c|c|}
\hline \multicolumn{5}{|c|}{ Carbohydrate liberated ( $\mu \mathrm{g} 100 \mathrm{mg}^{-1}$ oyster tissue $24 \mathrm{~h}^{-1}$ ) } \\
\hline Toluene/Thimerosal in assay tubes & $\begin{array}{r}150 \\
57\end{array}$ & $5.2(11)$ & 999. & $(12)$ \\
\hline \multicolumn{5}{|l|}{ ANOVA table for data presented above: } \\
\hline Source & $\mathrm{DF}$ & SS & F & $\mathrm{p}$ \\
\hline Oyster antibiotic treatment & 1 & 337197.7 & 2.44 & 0.1259 \\
\hline Toluene/Thimerosal in assay tubes & 1 & 4034977.0 & 29.19 & 0.0001 \\
\hline Interaction & 1 & 1294822.4 & 9.37 & 0.0038 \\
\hline Error & 42 & 138253.8 & & \\
\hline
\end{tabular}

Dietary induction of carbohydrases has been clearly demonstrated in other invertebrates, including copepods (Cox \& Willason 1981), mixed samples of zooplankton (Mayzaud \& Conover 1984) and amphipods (Borowsky 1984).

Treatment of oysters with antibiotics reduced bacterial populations in oyster stomach fluids below the concentrations detectable using direct counting techniques. However, antibiotic-treated oysters did not show a significantly reduced digestion or absorption of ${ }^{14} \mathrm{C}$ from Spartina alterniflora into hemolymph and tissue fractions, compared with untreated oysters (Tables $3 \& 5$ ). These results indicate that the digestion of cellulosic plant material was not dependent on bacteria in the stomach.

Further evidence that bacteria did not significantly contribute to cellulose digestion in oysters can be seen in the measured cellulase activities of tissue homogenates from oysters used in the feeding experiment (Table 6). No significant differences in the cellulase activities of antibiotic-treated oysters and of untreated oysters were observed. Furthermore, incubation of tissue homogenates with cellulose azure in the absence of Thimerosal and toluene indicated that bacteria from the oyster did not enhance cellulose breakdown in vitro; indeed, cellulose breakdown was significantly greater (ANOVA, $p<0.0001$ ) when toluene and Thimerosal were added to the assays to inhibit bacterial activity. This is possibly due to bacteria in the non-antibiotic treated assay tubes degrading cellulolytic enzymes from the oyster.

Lucas \& Newell (1984) calculated that style carbohydrases acting directly on plant detrital material may provide up to $40 \%$ of the carbon requirements of Crassostrea virginica, but their calculations did not take into account the possible rate-limiting step of $\beta$ glucosidase activity in the oyster's diverticula (Maya- sich \& Smucker 1986) nor the availability of refractory carbon to oysters in their natural environment. Therefore, we have calculated the potential contribution that refractory carbon can make to the carbon requirement of $C$. virginica, using data collected for a population of oysters in Broad Creek, a sub-estuary of Chesapeake Bay, Maryland.

At $25^{\circ} \mathrm{C}$ under ambient conditions, an oyster of $1 \mathrm{~g}$ dry tissue weight has a filtration rate of $5 \mathrm{l} \mathrm{h}^{-1}$ and an oxygen consumption of $1.0 \mathrm{ml} \mathrm{O}_{2} \mathrm{~h}^{-1}$ (Newell unpubl.) which is equivalent to $0.537 \mathrm{mg} \mathrm{C}$ respired $\mathrm{h}^{-1}$. Thus the oyster's total carbon requirement is $0.714 \mathrm{mg} \mathrm{h}^{-1}$, assuming that respiratory carbon requirements account for $75 \%$ of the total carbon requirement (Bayne \& Newell 1983, Lucas \& Newell 1984). The mean concentration of detrital carbon in the seston available to oysters in Broad Creek is ca $0.3 \mathrm{mg} \mathrm{l}^{-1}$ (Berg \& Newell 1986). This was estimated from the carbon concentration present during the winter when the carbon-to-chorophyll ratio was 275 . Values greater than 100 for this ratio indicate that only a small proportion of the carbon originates from living phytoplankton (Chervin et al. 1981). Therefore, an oyster filtering $5 \mathrm{l} \mathrm{h}^{-1}$ will ingest $1.5 \mathrm{mg}$ detrital $\mathrm{C} \mathrm{h} \mathrm{h}^{-1}$. Assuming a digestion efficiency of $1.27 \%$, as determined for refractory cellulosic material, the oyster will absorb $0.019 \mathrm{mg} \mathrm{C} \mathrm{h}^{-1}$. This will only provide $2.7 \%$ of the oyster's total carbon requirement.

These calculations indicate that it is unlikely that carbon from refractory plant detritus provides a large proportion of the oyster's carbon requirements. This suggests that the primary function of the oyster's cellulase enzymes may be to aid the digestion of other nutrients that are either contained within the cellulosic cell walls of algae or adsorbed onto cellulosic detrital particles.

The importance of carbon from Spartina alterniflora 
detritus to estuarine animals, including Crassostrea virginica, has been studied using stable carbon isotope ratios by Haines (1977), Montague et al. (1981) and Hughes \& Sherr (1983). They concluded that there was little evidence that the plant detritus was being directly assimilated by subtidal suspension-feeders in the Georgia marshes. Recently, Peterson et al. (1985) used the combined stable isotope ratios of carbon, nitrogen and sulphur to show that the ribbed mussel Geukensia demissa, living high within the marsh, may derive up to $80 \%$ of its diet from $S$. alterniflora. According to our results, however, the stable isotope ratios of $C$. virginica living in salt marshes would not reflect direct utilization of refractory $S$, alterniflora detritus as a food source because of its poor digestibility by the oyster. Indirect utilization of $S$. alterniflora material via digestion and assimilation of microheterotrophic decomposers either free living or attached to plant detrital particles in the seston (Newell \& Field 1983) is likely to be a more significant source of nutrition for oysters. Studies to determine the exact contributions that cellulose makes to the seasonal carbon requirements of natural populations of $C$. virginica and $G$. demissa are currently being undertaken in our laboratories.

Acknowledgements. We are grateful to Mrs Shelley Sulkin and Ms Linda Franklin for technical assistance, and to Dr. Ron Benner for determining the specific activity of the ${ }^{14} \mathrm{C}$ labelled cellulosic material. We thank Dr. Ray Thompson for constructive review of our manuscript. This research was supported by a grant (\# OCE-8000264) from the Biological Oceanography division of the National Science Foundation to Drs. R. I. E. Newell, C. J. Langdon and H. Ducklow. The U.S. Government is authorized to produce and distribute reprints for governmental purposes, notwithstanding any copyright notation that may appear hereon.

\section{LITERATURE CITED}

Bayne, B. L., Newell, R. C. (1983). Physiological energetics of marine molluscs. In: Saleuddin, A. S. M., Wilbur, K. M. (ed.) The Mollusca, Vol. 4, Physiology, Part 1. Academic Press, New York, p. 407-515

Benner, R., Maccubbin, A. E., Hodson, R. E. (1984). Preparation, characterization and microbial degradation of specifically radiolabeled $\left[{ }^{14} \mathrm{C}\right]$ lignocelluloses from marine and freshwater macrophytes. Appl. environ. Microbiol. 47: 381-389

Berg, J. A., Newell, R. I. E. (1986). Temporal and spatial variations in the composition of seston available to the suspension feeder Crassostrea virginica. Estuar. coast. Shelf. Sci. 23: in press

Borowsky, R. (1984). Environmental control of amylase phenotype in amphipods of the genus Gammarus. Biol. Bull. mar. biol. Lab., Woods Hole 167: 647-657

Chervin, M. B., Malone, T. C., Neale, P. J. (1981). Interactions between suspended organic matter and copepod grazing in the plume of the Hudson River. Estuar, coast Shelf. Sci. 13: $169-184$

Coston-Clements, L., Ferguson, R. L. (1985). Proximate composition and distribution of radioactive label in laboratory cultured Spartina alterniflora Loisel. J. exp. mar. Biol. Ecol. 93: 259-271

Cox, J. L., Willason, S. W. (1981). Laminarase induction in Calanus pacificus. Mar. Biol. Lett. 2: 307-311

Crosby, N. D., Reid, R. G. (1971). Relationships between food, physiology and cellulose digestion in the Bivalvia. Can. J. Zool. 49: 617-622

Dubois, M., Gilles, K. A., Hamilton, J. K., Rebers, P. A., Smith, F. (1956). Colorimetric method for the determination of sugars and related substances. Analyt. Chem. 28: 350-356

Ferguson, R. L., Williams, R. B. (1974). A growth chamber for production of ${ }^{14} \mathrm{C}$-labelled salt marsh plant and its application to smooth cordgrass, Spartina alterniflora Loisel. J. exp. mar. Biol. Ecol. 14: 251-259

Fisher, W. S., Newell, R. I. E. (1986). Salinity effects on granular hemocytes of the American oyster, Crassostrea virginica. Biol. Bull. mar. biol. Lab., Woods Hole 170: $122-134$

Fong, W., Mann, K. H. (1980). Role of gut flora in the transfer of amino acids through a marine food chain. Can. J. Fish. aquat. Sci. 37 : 88-96

Galtsoff, P. S. (1964). The American oyster Crassostrea virginica Gmelin. Fish. Bull. 64: 1-480

Haines, E. B. (1977). The origin of detritus in Georgia salt marshes. Oikos 29: 254-260

Halliwell, G. (1966). Solubilization of native and derived forms of cellulose by cell-free microbial enzymes. Biochem. J. 100: 315-320

Heinle, D. R., Flemer, D. A. (1976). Flows of materials between poorly flooded tidal marshes and an estuary. Mar Biol. 35: 359-373

Holland, D. L., Gabbot, P. A. (1971). A micro-analytical scheme for the determination of protein, carbohydrate, lipid and RNA levels in marine invertebrate larvae. J. mar. biol. Ass. U.K. 51: 659-668

Hughes, E. H., Sherr, E. B. (1983). Subtidal food webs in a Georgia estuary: ${ }^{13} \mathrm{C}$ analysis. J. exp. mar. Biol. Ecol. 67 : $227-242$

Koopmans, J. J. C. (1970). Cellulases in molluscs. I. The nature of the cellulases in Helix pomata and Cardium edule. Neth. J. Zool. 20: 445-463

Kristensen, J. H. (1972). Carbohydrates of some marine invertebrates with notes on their food and on the natural occurrence of the carbohydrates studied. Mar. Biol. 14: 130-142

Langdon, C. J., Bolton, E. T. (1984). A microparticulate diet for a suspension feeding bivalve mollusc, Crassostrea virginica (Gmelin). J. exp. mar. Biol. Ecol. 82: 239-258

Lowry, O. H., Josenbrough, N. J., Farr, A. L., Randall, R. J. (1951). Protein measurement with the folin phenol reagent. J. biol. Chem. 193: 265-275

Lucas, M. I., Newell, R. C. (1984). Utilization of saltmarsh detritus by two estuarine bivalves: Carbohydrase activity of crystalline style enzymes of the oyster Crassostrea virginica (Gmelin) and the mussel Geukensia demissa (Dillwyn). Mar. Biol. Lett. 5: 275-290

Mandels, M., Andreotti, R., Roche, C. (1976). Measurement of saccharifying cellulase. Biotechnol. Bioeng. Symp. 6: 21-33

Mathers, N. F. (1973). A comparative histochemical survey of enzymes associated with the processes of digestion in Ostrea edulis and Crassostrea angulata (Mollusca: Bivalvia). J. Zool. Lond. 169: 169-179

Mayasich, S. A., Smucker, R. A. (1986). Glycosidases in the 
American oyster, Crassostrea virginica Gmelin, digestive tract. J. exp. mar. Biol. Ecol. 95: 95-98

Mayzaud, P., Conover, R. J. (1984). Distribution of digestive enzymes in zooplankton during the spring bloom in a Nova Scotia inlet. Can. J. Fish. Aquat. Sci. 41: 245-252

McIntire, G. L., Dunstan, W. M. (1976). Non-structural carbohydrates in Spartina alterniflora Loisel. Botanica mar. 19: 93-96

Montague, C. L., Bunker, S. M., Haines, E. B., Pace, M. L., Wetzel, R. L. (1981). Aquatic macroconsumers. In: Pomeroy, L. R., Wiegert, R. G. (ed.) The ecology of a salt marsh. Springer-Verlag, New York, p. 69-86

Morton, B. (1983). Feeding and digestion in Bivalvia. In: Saleuddin, A. S. M., Wilbur, K. M. (ed.) The Mollusca, Vol. 5., Physiology, Part 2. Academic Press, New York, p. 65-147

Mountford, K. (1980). Aspects of the ecology of a small estuarine embayment. Mar. Biol. 61: 53-67

Newell, R. C., Field, J. G. (1983). The contribution of bacteria and detritus to carbon and nitrogen flow in benthic community. Mar. Biol. Lett. 4: 249-257

Payne, D. W., Thorpe, N. A., Donaldson, E. M. (1972). Cellulolytic activity and a study of the bacterial population in the digestive tract of Scrobicularia plana (Da Costa). Proc. malac. Soc. Lond. 40: 147-160

Peterson, B. J., Howarth, R. W., Garritt, R. H. (1985). Multiple stable isotopes used to trace the flow of organic matter in estuarine food webs. Science 227: 1361-1363

Pickral, J. C., Odum, W. E. (1976). Benthic detritus in a saltmarsh tidal creek. In: Wiley, M. (ed.) Estuarine processes, Vol. II. Academic Press, New York, p. 280-292
Porter, K. G., Feig, Y. S. (1980). The use of DAPI for identifying and counting aquatic microflora. Limnol. Oceanogr. 25: 943-948

Rice, D. L. (1982). The detritus nitrogen problem: new observations and perspectives from organic geochemistry. Mar Ecol. Prog. Ser. 9: 153-162

Smith, K. K., Good, R. E., Good, N. F. (1979). Production dynamics for above and below ground components of a New Jersey Spartina alterniflora tidal marsh. Estuar. coast. Shelf Sci. 9: 189-201

Squiers, E. R., Good, R. E. (1974). Seasonal changes in the productivity, caloric content and chemical composition of a population of salt marsh cordgrass (Spartina alterniflora). Chesapeake Sci. 15: 63-71

Strickland, J. D. H., Parsons, T. R. (1972). A practical handbook of seawater analysis. Bull. Fish. Res. Bd Can. 167: $1-310$

Teal, J. M. (1962). Energy flow in the salt marsh ecosystem of Georgia. Ecology 43: 614-624

Waterbury, J., Calloway, C. B., Turner, R. D. (1983). A cellulolytic nitrogen-fixing bacterium cultured from the gland of Deshayes in shipworms (Bivalvia: Teredinidae). Science 221: 1401-1403

Whistler, R. L. (1963). Methods in carbohydrate chemistry, Vol III, Cellulose. Academic Press, New York

Wojtowicz, M. B. (1972). Carbohydrases of the digestive gland and the crystalline style of the Atlantic deep-sea scallop (Placopecten magellanicus Gmelin). Comp. Biochem. Physiol. 43 A: 131-141 